\title{
EXTREMITY STRENGTHENING EXERCISE ON NEONATES RECEIVING PHOTOTHERAPY
}

\author{
Eni Rahmawati, Dian Susmarini, Meivita Dewi Purnamasari
}

Faculty of Health Sciences, Jenderal Soedirman University, Jl. Dr. Soeparno, Karangwangkal, Purwokerto

\begin{abstract}
Neonatal jaundice is a clinical condition found in infants, which is characterized by yellow staining of the skin and sclera due to the accumulation of unconjugated bilirubin excess. This is the leading cause of death in $60 \%-80 \%$ of newborns. This research aimed to investigate the effects of an extremity strengthening exercise on neonates, who were receiving phototherapy in terms of defecation frequency, vital signs, enteral feeding and body weight. In this quasi experimental study, 34 aterm neonates with jaundice, who had been admitted for phototherapy, were selected through quota sampling. Subjects were assigned to either an exercise or a control group. The neonates in the exercise group received a passive extremities exercise for 15 to 20 minutes on their extremities twice a day for 3 days, while the neonates in the control group did not receive the exercise. Statistical analysis was performed using an independent $t$ test and the Mann Whitney test. Demographic and clinical characteristics, the defecation frequency, vital signs, total feeding amount and body weight were identified and compared between the two groups. On the third day, the exercise group showed a significantly higher defecation frequency $(p=0.000)$ and a significant increase in their respiration rate $(p=0.029)$; however, there was no significant increase in their vital signs (heart rate $p=0.583$ and temperature $p=0.807$;) enteral feeding rate $(p=0.202)$ and body weight $(p=0.181)$. It can be concluded that the extremity strengthening exercise can increase the defecation frequency in neonates with jaundice who are receiving phototherapy. The amount of exercise carried out was limited in order to stabilise body temperature and heart rate.
\end{abstract}

Keywords: exercise, neonates, phototherapy, hyperbilirubinemia

\section{ABSTRAK}

Ikterus neonatal adalah kondisi klinis pada bayi yang ditandai dengan warna kuning pada kulit dan sklera karena akumulasi kelebihan bilirubin yang tidak terkonjugasi. Hal ini menjadi penyebab utama kematian pada $60 \%-80 \%$ bayi baru lahir. Penelitian bertujuan untuk mengetahui efek latihan penguatan ekstremitas pada neonatus dengan frekuensi defekasi, tanda-tanda vital, intake makanan enteral dan berat badan yang menerima fototerapi. Penelitian quasi experimental dengan jumlah 34 neonatus aterm dengan ikterus yang sedang menjalani fototerapi melalui kuota sampling. Responden terbagi menjadi kelompok latihan dan kelompok kontrol. Neonatus dalam kelompok latihan menerima latihan ekstremitas pasif selama 15 hingga 20 menit pada ekstremitas, dua kali sehari selama 3 hari, sedangkan kelompok kontrol tidak menerima latihan apa pun. Analisis statistik menggunakan uji $t$ independen dan uji mann-whitney. Karakteristik demografi dan data klinis, frekuensi buang air besar, tanda vital, jumlah makan total dan berat badan diidentifikasi dan dibandingkan antara dua kelompok. Pada hari ketiga, kelompok latihan menunjukkan frekuensi buang air besar meningkat secara signifikan $(p=0,000)$ dan signifikan pada frekuensi pernapasan $(p=0,029)$; tidak signifikan pada tanda-tanda vital (frekuensi nadi $p=0,583$ dan suhu $p=0,807 ;$ ) pemberian makanan enteral $(p=0,202)$ dan berat badan $(p=0,181)$. Latihan pengutan ekstremitas dapat meningkatkan frekuensi buang air besar pada neonatus dengan ikterus yang menerima fototerapi. Efek latihan terbatas untuk suhu dan frekuensi nadi.

Kata kunci: latihan, neonatus, fototerapi, hiperbilirubinemia 


\section{INTRODUCTION}

The management of healthy babies who are without risk factors does not necessarily involve medical therapy, however in order to treat jaundice in healthy infants (physiological icterus), there are several methods including drinking regularly and frequent breastfeeding, light therapy, and in accordance with WHO guidelines, babies returning home from hospital before 48 hours have elapsed since the birth should be re-checked immediately. While for the management of pathological conditions, this can be done with light therapy (Anggraeni, Aji, Setiyani, Kartikasari, \& Rahmawati, 2018; Muchowski, 2014; Reis et al., 2017). Phototherapy is a therapy, performed using light from a special highintensity fluorescent lamp, which, in general, is effective in reducing serum bilirubin and preventing jaundice (Rahmawati, Susmarini, Lestari, \& Putri, 2019; Rahmawati, Susmarini, Lestari, \& Utami, 2018).

The effectiveness of phototherapy depends on the intensity of the light produced by the light source. Light intensity is the number of photons given per centimeter on the exposed body surface. A standard phototherapy light must provide $8-10 \mu \mathrm{W} / \mathrm{cm}^{2} / \mathrm{nm}$ beam intensity with wavelengths of 430 to 490 nm (H.S., D.M., A.S., R., \& L.M., 2016). The American Academy of Pediatrics (AAP) defines intensive phototherapy as phototherapy, which produces light intensity of at least $30-40 \mu \mathrm{W} / \mathrm{cm}^{2} / \mathrm{nm}$ and wavelengths that can cover the entire body surface (Wells, Ahmed, \& Musser, 2013). The intensity determines the effectiveness of phototherapy that is, that the higher the light intensity, the faster the decrease in serum bilirubin levels (Eghbalian, Rafienezhad, \& Farmal, 2017; Olusanya, Ogunlesi, \& Slusher, 2014).

Physical exercise is a therapy adapted from the Moyer-Mileur protocol, which was established from passive ROM movements and soft compression movements on the 6 large joints of the extremities which include the shoulders, the elbow, the wrists, hips, knees and ankles (Basiri-Moghadam, BasiriMoghadam, Kianmehr, \& Jani, 2015).
Based on research conducted by Lin et.al, massage therapy (i.e. physical movement) was able to stimulate the vagus nerve, which in turn will increase the intestinal movement and eventually reduce enterohepatic circulation, and thereby increase bilirubin excretion. An increase in intestinal movement intensifies defecation frequency, which allows the baby to release large amounts of meconium, which also contains bilirubin (C.-H. Lin, Yang, Cheng, \& Yen, 2015). Physiologically, the therapeutic effect of massage therapy on subcutaneous tissue increases blood circulation, lymph and fluids in tissues, which will then increase the collection and removal of waste products from the body such as bilirubin (Chen, Sadakata, Ishida, Sekizuka, \& Sayama, 2011).

Basiri et al. stated that physical movements in infants can facilitate the excretion of meconium, shorten the time required for changes in bilirubin levels and its reabsorption into the blood through the liver transport system, hence reducing the incidence of hyperbilirubinemia (BasiriMoghadam et al., 2015). Physical exercise stimulates bone formation and increases bone mineral density. Physical exercise in premature babies in hospitals can also increase bone demineralization and osteopenia prematurity, which then results in an increase of growth, increased bone mass, and increased body weight. Other studies suggested that passive physical exercise of the range of motion (ROM) can increase muscle mass and help early maturation of the neuromuscular system in premature infants (Yatin Verma, 2015). The research exercise is performed on neonates who have hyperbilirubin and are undergoing phototherapy, not on healthy babies. Another difference with the previous study is that it was only done on the exercise of the extremities, not normal body massage.

\section{PURPOSE}

Considering the above facts, our research was aimed at examining the effect of exercise (for neonates undergoing phototherapy) on the defecation frequency, vital signs (respiration rate, heart rate, and 
temperature), total feeding frequency/ amount and body weight.

\section{METHOD}

This research has received ethical approval from the hospital ethics commission. The design of the research was quasiexperimental pretest-posttest design with control group. This research was carried out in a rural hospital in Banyumas District, Central Java. The quota sampling technique meant there were 17 neonates in each group. According to Gay and Diehl (1992), cited in Arikunto (2010), it was stated that in experimental studies, the recommended sample size is 15 samples per group with the anticipated drop out rate being $10 \%$. See Figure 1. Consort chart for the study. The inclusion criteria in this study included babies with a gestational age of 34-41 weeks, an APGAR score at birth of 8-10 and who were receiving phototherapy due to hyperbilirubinemia. The exclusion criteria for this study were the presence of congenital abnormalities, infections, and obstruction of the digestive tract. The exercise in this research is a physical therapy adapted from the Moyer-Mileur protocol, which consists of passive ROM movements and soft compression on the six large joints of the extremities, namely the shoulders, the elbows, wrists, hips, knees and ankles. Neonates in the exercise group received a passive extremities exercise for 15 to 20 minutes on extremities twice a day for 3 days, while the control group did not receive the exercise (Moyer-Mileur, Haley, Slater, Beachy, \& Smith, 2013). Phototherapy is an intervention for infants with jaundice, which is an increase of bilirubin levels in the extravascular tissue, characterized by visible yellowness on the skin, conjunctiva, mucosa and other body parts. The independent t-test and the Mann Whitney test were used to analyze the differences before and after the physical exercise therapy, with a level of confidence at $95 \%(\alpha=0.05)$.

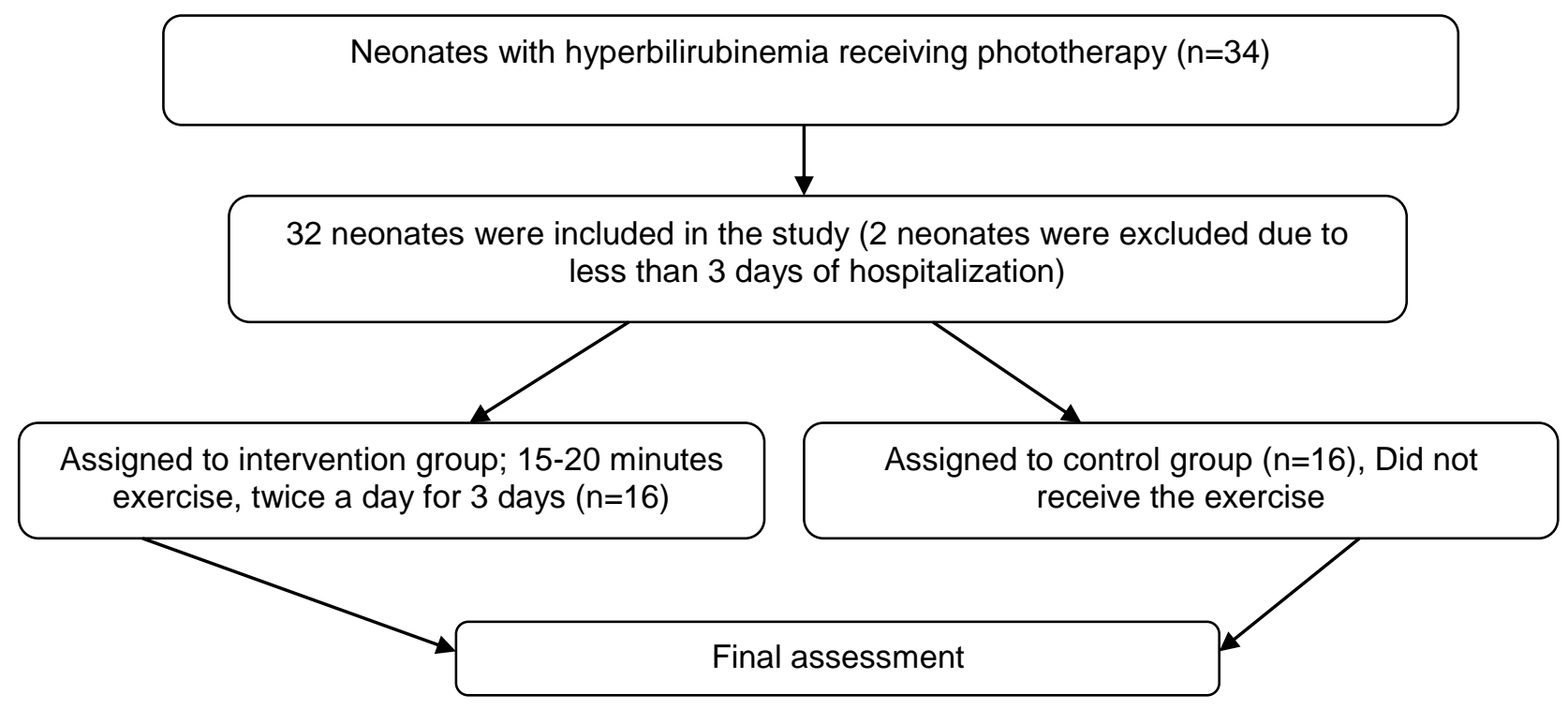

Figure 1. Consort chart for the study

\section{RESULTS}

The intervention and control groups were similar in terms of baseline characteristics as described below.

Table.1 Baseline characteristics of participants $(n=34)$

\begin{tabular}{llcc}
\hline Variables & Item & Intervention(n = 17) & Control group $(\mathbf{n}=\mathbf{1 7})$ \\
\hline Baby sex & Male & $10(58.8 \%)$ & $7(41.2 \%)$ \\
& Female & $7(41.2 \%)$ & $10(58.8 \%)$ \\
Enteral feeding & Breast milk & $0(0 \%)$ & $0(0 \%)$ \\
& Formula milk & $1(5.9 \%)$ & $2(11.8 \%)$ \\
\multirow{3}{*}{ Type of delivery } & Mix & $16(94.1 \%)$ & $15(88.2 \%)$ \\
& Caesarean section & $10(58.8 \%)$ & $7(41.2 \%)$ \\
& Spontaneous & $3(17.6 \%)$ & $7(41.2 \%)$ \\
& Vacuum Extract & $4(23.5 \%)$ & $3(17.6 \%)$ \\
\hline
\end{tabular}




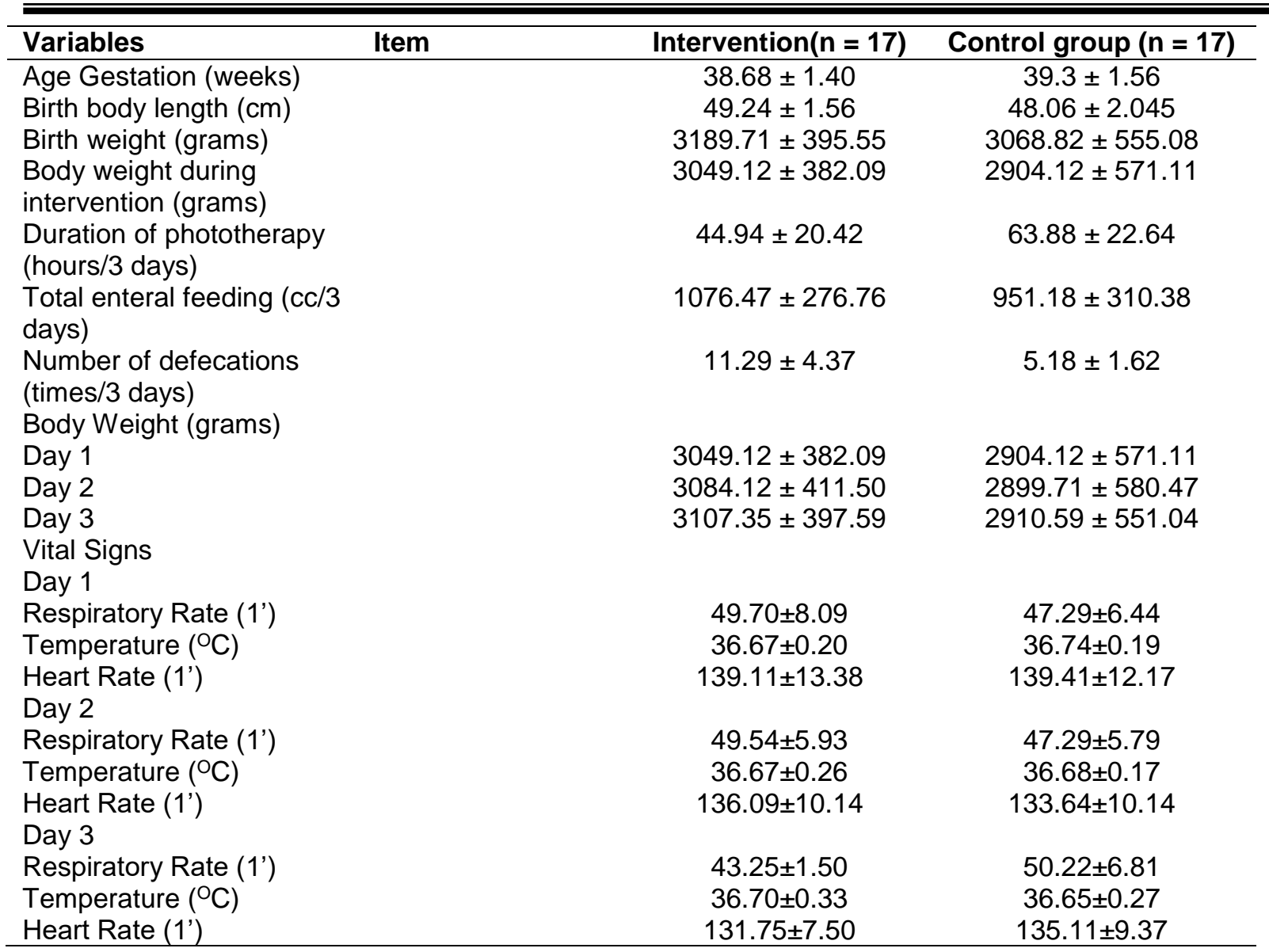

Table.2 Mean scores of frequency of defecation, total enteral feeding, body weight and vital signs in intervention and control groups in three days $(n=32)$

\begin{tabular}{|c|c|c|c|}
\hline Variable & $\begin{array}{c}\text { Exercise }(n=16) \\
(\text { mean } \pm \text { SD) }\end{array}$ & $\begin{array}{c}\text { Control groups }(n=16) \\
(\text { mean } \pm \text { SD) }\end{array}$ & p-value \\
\hline $\begin{array}{l}\text { Frequency of defecation } \\
\text { (times/3 days) }\end{array}$ & $11.29 \pm 4.37$ & $5.18 \pm 1.62$ & 0.000 * \\
\hline Total enteral feeding (cc/3 days) & $1076.47 \pm 276.76$ & $951.18 \pm 310.38$ & 0.202 \\
\hline Body Weight (grams) ${ }^{* * *}$ & $3107.35 \pm 397.59$ & $2910.59 \pm 551.04$ & 0.181 \\
\hline Respiratory rate $\left(1^{\prime}\right)^{\star * *}$ & $43.25 \pm 1.50$ & $50.22 \pm 6.81$ & $0.029^{*}$ \\
\hline Temperature $(\mathrm{OC})^{\star \star}$ & $36.70 \pm 0.33$ & $36.65 \pm 0.27$ & 0.807 \\
\hline Heart Rate $\left(1^{\prime}\right)^{\star *}$ & $131.75 \pm 7.50$ & $135.11 \pm 9.37$ & 0.543 \\
\hline
\end{tabular}

*significant, ${ }^{* *}$ independent $t$ test, ${ }^{* * *}$ Mann Whitney test

The frequency of defecation increased significantly on 3rd day for the intervention group $(p=0.000)$. All of the respondents (from both groups) showed an increase in fluid intake on the 2nd and 3rd days of the experiment compared to the level of fluid intake on the first day. Even though the increased fluid intake in both groups resulted in changes in body weight, there was no statistically significant difference between the groups (Table 2). The neonates' vital signs were observed and recorded for 3 days. There was a decrease in the respiratory rate in the intervention group on the third day, but there was no difference in the temperature and heart rate for the neonates the intervention group or the control group.

\section{DISCUSSION}

According to the findings of this study, the frequency of defecation increased significantly on the third day in the intervention group. According to Lin et.al. (2015), massage therapy (i.e. physical exercise) is able to stimulate the vagus nerve in neonates, which will then increase intestinal movement and reduce 
enterohepatic circulation, which will then eventually increase bilirubin excretion (C. H. Lin, Yang, Cheng, \& Yen, 2015). Increased bowel movement will also increase the frequency of defecation, which allows the baby to release large amounts of meconium, which also contains bilirubin. Physiologically, the therapeutic effect on subcutaneous tissue is to increase blood circulation, lymph and fluids in tissues, which will then increase the collection and removal of body waste products such as bilirubin (Karbandi, Boskabadi, Esmaeily, \& Kalateh Molaee, 2016; C.-H. Lin et al., 2015).

Basiri et al. stated that physical exercise in infants can facilitate the excretion of meconium, shorten the duration of time needed for changes in bilirubin and its reabsorption into the blood through the liver transport system. This process results in the decrease of the hyperbilirubinemia occurrence (BasiriMoghadam et al., 2015). Physical exercise will stimulate bone formation and increase bone mineral density. Physical exercise carried out on premature babies will also increase the rate of bone demineralization and osteopenia prematurity hence the rate of growth, bone mass, and body weight increased. Other studies suggested that passive physical exercise of the range of motion (ROM) can increase muscle mass and facilitate early maturation of the neuromuscular system in premature infants (Yatin Verma, 2015).

The results of our study indicated that the neonates' body weight was not significantly different between the intervention and control groups. This result is consistent with some reports in previous studies (Lin et al. (2015), which states that weight gain after massaging is caused by elevated levels of insulin (IGF-1) that can also lower stress and gastric motility, leading to a more efficient absorption of food. In Lin et al's research, the lack of a significant increase in weight gain after massage was caused due to the age of younger respondents (average age: $4.9 \pm$ 2.5 days in group massage; $4.5 \pm 1.7$ days in the control group). In addition, it is possible that the duration of massage therapy is too short to stimulate insulin secretion and IGF-1.
Moreover, the recent literature has indicated that massage therapy promotes weight gain in preterm infants who receive a moderate-pressure massage for 10 minutes three times per day over 5 days (WHO, 2017). This study also demonstrated that massaged infants gained weight significantly more than infants in the control group at 2 months of age. Other studies reported that both body weight and height significantly increased in massaged infants compared with that of the control group after 2 and 14 week intervals of massage therapy (Abdallah, Badr, \& Hawwari, 2013; Bal Yılmaz \& Conk, 2009; Moyer-Mileur et al., 2013). Field et al. showed that preterm neonates who received massage therapy for 5 days had greater increases in weight gain, serum insulin levels, and insulin-like growth factor-1 (IGF-1) (Field et al., 2008).

There was a decrease in the respiratory rate in the intervention group on the third day, but there was no difference in the temperature and heart rate for both groups. The activity of the vagus nerve fibers can affect lungs. A study conducted at the Touch Research Institute has showed that twenty minutes of massage every night for asthmatic children can help them to breathe better. This positive finding led to further questions on whether massage therapy, provided by parents, can improve the baby's mental, motoric and social development (Moran et al., 2015; Trivedi, 2015).

This study found no difference in temperature between neonates in the intervention group and the control group. This is beneficial as babies do not lose body heat during the massage. Research conducted by Smith et al. that applied moderate pressure strokes with a kinesthetic movement at extremities, which asserted that higher heart rate variability indicates increased vagal tone. Increased vagal activity when induced by massage has been suggested as one potential mechanism for higher weight gain in infants who have been receiving massage therapy (Smith et al., 2013). The time and small number of samples became limitations in this study. Nursing 
implications: The results of this study can help to increase the frequency of defecation and indirectly reduce bilirubin levels in neonates who are receiving phototherapy.

\section{CONCLUSION AND RECOMMENDA TION}

Extremity strengthening exercise can increase the defecation frequency in neonates receiving phototherapy for jaundice treatment. Exercise can help to stabilize the respiratory rate as well as reduce the level of stress while receiving phototherapy. The effect of exercise was limited to stabilize the temperature and heart rate. It is highly recommended that an effective, inexpensive, and simple program be produced for clinical nurses because the exercise can help to reduce the long of stay neonates in hospitals.

\section{ACKNOWLEDGEMENTS}

This study was supported by a research grant from the Jenderal Soedirman University, Indonesia.

\section{REFERENCES}

Abdallah, B., Badr, L. K., \& Hawwari, M. (2013). The efficacy of massage on short and long term outcomes in preterm infants. Infant Behavior and Development. https://doi.org/10.1016 /j.infbeh.2013.06.009

Anggraeni, M. D., Aji, B., Setiyani, R., Kartikasari, A., \& Rahmawati, E. (2018). How do modern parents deal with cultural beliefs about breastfeeding? A qualitative study. British Journal of Midwifery. https://doi.org/10.12968/bjom.2018.2 6.9 .605

Arikunto. (2010). Suharsimi Arikunto.pdf. In Prosedur Penelitian Suatu Pendekatan Praktik-Revisi ke $X$.

Bal Yılmaz, H., \& Conk, Z. (2009). The effect of massage by mothers on growth in healthy full term infants. International Journal of Human Sciences.
Basiri-Moghadam, M., Basiri-Moghadam, K., Kianmehr, M., \& Jani, S. (2015). The effect of massage on neonatal jaundice in stable preterm newborn infants: A randomized controlled trial. Journal of the Pakistan Medical Association.

Chen, J., Sadakata, M., Ishida, M., Sekizuka, N., \& Sayama, M. (2011). Baby Massage Ameliorates Neonatal Jaundice in Full-Term Newborn Infants. The Tohoku Journal of Experimental Medicine. https://doi.org/10.1620/tjem.223.97

Dalili, H., Sheikhi, S., Shariat, M., \& Haghnazarian, E. (2016). Effects of baby massage on neonatal jaundice in healthy Iranian infants: A pilot study. Infant Behavior and Development. https://doi.org/10.1016 /j.infbeh.2015.10.009

Eghbalian, F., Rafienezhad, H., \& Farmal, J. (2017). The lowering of bilirubin levels in patients with neonatal jaundice using massage therapy: $A$ randomized, double-blind clinical trial. Infant Behavior and Development. https://doi.org/10.1016 /j.infbeh.2017.05.002

Field, T., Diego, M., Hernandez-Reif, M., Dieter, J. N. I., Kumar, A. M., Schanberg, S., \& Kuhn, C. (2008). Insulin and insulin-like growth factor1 increased in preterm neonates following massage therapy. Journal of Developmental and Behavioral Pediatrics. https://doi.org/10.1097/D BP.0b013e3181856d3b

H.S., S., D.M., Y., A.S., S., R., E.-B., \& L.M., S. (2016). High-intensity lightemitting diode vs fluorescent tubes for intensive phototherapy in neonates. Paediatrics and International Child Health. https://doi.org/10.1179/2046905515 Y.0000000006 
Karbandi, S., Boskabadi, H., Esmaeily, H., \& Kalateh Molaee, M. (2016). Effects of massage on duration of phototherapy in premature infants admitted to a neonatal intensive care unit. Journal of Babol University of Medical Sciences.

Lin, C.-H., Yang, H.-C., Cheng, C.-S., \& Yen, C.-E. (2015). Effects of infant massage on jaundiced neonates undergoing phototherapy. Italian Journal of Pediatrics, 41, 94. https://doi.org/10.1186/s13052-0150202-y

Lin, C. H., Yang, H. C., Cheng, C. S., \& Yen, C. E. (2015). Effects of infant massage on jaundiced neonates undergoing phototherapy. Italian Journal of Pediatrics. https://doi.org/ 10.1186/s13052-015-0202-y

Moran, C. A., Cacho, R. de O., Cacho, E. W. A., Sousa, K. G., de Souza, J. C., Filho, G. G. da F., \& Pereira, S. A. (2015). Use of music during physical therapy intervention in a neonatal intensive care unit: A randomized controlled trial. Journal of Human Growth and Development. https://doi.org/10.7322/jhgd.103004

Moyer-Mileur, L. J., Haley, S., Slater, H., Beachy, J., \& Smith, S. L. (2013). Massage improves growth quality by decreasing body fat deposition in male preterm infants. Journal of Pediatrics. https://doi.org/10.1016/j. jpeds.2012.08.033

Muchowski, K. E. (2014). Evaluation and treatment of neonatal hyperbilirubin emia. American Family Physician, 89(11), 873-878.

Olusanya, B. O., Ogunlesi, T. A., \& Slusher, T. M. (2014). Why is kernicterus still a major cause of death and disability in low-income and middle-income countries?. Archives of Disease in Childhood, 99(12), 1117-1121. https://doi.org/ 10.1136/archdischild-2013-305506
Rahmawati, E., Susmarini, D., Lestari, P., \& Putri, A. D. (2019). Physical Stimulation For Hiperbilirubin. IOP Conference Series: Earth and Environmental Science. https://doi. org/10.1088/1755-1315/255/1/01200 1

Rahmawati, E., Susmarini, D., Lestari, P., \& Utami, A. (2018). Psysical Stimulation For Hyperbilirubinemia. In 1st International Conference on Multidisciplinary Approaches for Sustainable Rural Development (ICMA-SURE). Purwokerto: Research and Public Service Institute, Jenderal Soedirman University.

Reis, E. M. A., Nogueira, M., Silva, C. T., Rosário, M., Silva, J. S., Silva, G., \& Guimarães, H. (2017). Neonatal jaundice and its main risk factors - $A$ cross-sectional study. Cogent Medicine. https://doi.org/10.1080/23 31205X.2017.1408251

Smith, S. L., Lux, R., Haley, S., Slater, H., Beechy, J., \& Moyer-Mileur, L. J. (2013). The effect of massage on heart rate variability in preterm infants. Journal of Perinatology. https://doi.org/10.1038/jp.2012.47

Trivedi, D. (2015). Cochrane Review Summary: Massage for promoting mental and physical health in typically developing infants under the age of six months. Primary Health Care Research \& Development. https://doi.org/10.1017/S146342361 4000462

Wells, C., Ahmed, A., \& Musser, A. (2013). Strategies for Neonatal Hyperbiliru binemia: A LITERATURE REVIEW. The American Journal of Maternal Child Nursing, 38(December), 377382. https://doi.org/10.1097/NMC.0b 013e3182a1fb7a 
Jurnal Keperawatan Soedirman 15 (1) 2020 : 33 - 40

WHO. (2017). Care of the preterm and low-birth-weight newborn. WHO.

Yatin Verma, D. (2015). Neonatal Jaundice. YUVA Journal of Medical
Sciences. https://doi.org/10.1093/tro pej/fms051 